\title{
Pengaruh Penerapan Sistem Administrasi Perpajakan Modern Terhadap Kepatuhan Wajib Pajak Orang Pribadi Di Kota Manado (Studi Kasus Pada Kantor Pelayanan Pajak Pratama Manado)
}

\author{
Oleh \\ Evalin Yuanita Tologana \\ Meily Kalalo
}

\begin{abstract}
ABSTRAK
Tujuan diadakannya penelitian ini adalah untuk mengetahui pengaruh penerapan sistem administrasi perpajakan modern terhadap kepatuhan wajib pajak orang pribadi di kota manado serta seberapa besar pengaruh tersebut.

Penelitian tersebut dilakukan pada 100 wajib pajak orang pribadi yang berdomisili di daerah kecamatan Malalayang dengan memberikan sejumlah pertanyaan dalam bentuk kuesioner yang diukur dengan skala likert.

Metode penelitian yang digunakan dalam penelitian ini adalah analisis statistik deskriptif berupa analisis regresi linear sederhana termasuk didalamnya untuk mengetahui koefisien korelasi dan koefisien determinasi untuk menguji hipotesis uji t. Data yang terkumpul dianalisa dengan menggunakan bantuan software sttistik SPSS version 17.

Hasil analisis regresi yang diperoleh adalah $\mathrm{Y}=13,428+0,367 \mathrm{X}+$ e. Persamaan diatas memperlihatkan nilai dari koefisien $X$ sebesar positif $(0,367)$. Ini berarti variabel penerapan sistem administrasi perpajakan modern berpengaruh positif terhadap kepatuhan wajib pajak. Apabila penerapan sistem administrasi perpajakan modern mengalami peningkatan maka kepatuhan wajib pajak orang pribadi juga akan meningkat dan sebaliknya. Dari hasil uji $\mathrm{t}$ diketahui $\mathrm{t}_{\text {hitung }}$ untuk variabel pengetahuan wajib pajak $=3,387$ dan $t_{\text {tabel }}=1,660$. Jadi dapat dilihat bahwa $t_{\text {hitung }}>t_{\text {tabel }}$ maka $H_{0}$ ditolak $\mathrm{H}_{\mathrm{a}}$ diterima, juga dapat dilihat dari hasil signifikan $<0,05$ maka $\mathrm{H}_{0}$ ditolak $\mathrm{H}_{\mathrm{a}}$ diterima, artinya variabel sistem admininstrasi perpajakan modern berpengaruh positif dan signifikan terhadap kepatuhan wajib pajak orang pribadi.
\end{abstract}

\section{ABSTRACT}

The objective of this study was to determine the effect of the application of modern tax administration system to the individual taxpayer compliance in Manado city and how much influence it. The study was conducted on 100 individual taxpayers who live in the area Malalayang districts by providing a number of questions in the form of a questionnaire that measured with a Likert scale . The method used in this study is a descriptive statistical analysis of simple linear regression analysis including correlation coefficients to determine the coefficient of determination and t-test to test the hypothesis. The data were analyzed using SPSS statistical software version 17 . The results of the regression analysis is $Y=13.428+0.367 X+e$. The above equation shows the value of the coefficient of $X$ by a positive ( 0.367 ). This means that the variable application of modern tax administration system has a positive effect on tax compliance. If the application of modern tax administration system to increase the compliance of individual taxpayers will also increase and vice versa. From the results of the t test for variables known $t_{\text {value }}$ of knowledge taxpayer is 3.387 while $t_{\text {table }}$ is 1.660 . So it can be seen that $\mathrm{HO}$ is rejected while Ha accepted, means that modern tax system variables admininstrasi positive and significant effect on an individual taxpayer compliance. 


\section{PENDAHULUAN}

\subsection{Latar Belakang Penelitian}

Reformasi kebijakan perpajakan sebenarnya telah dimulai sejak tahun 1983 dengan diterbitkannya seperangkat peraturan perundang-undangan dibidang perpajakan yang menggantikan perundang-undangan yang dibuat oleh pemerintah kolonial belanda seperti ordonansi pajak pendapatan 1944 dan ordonansi pajak perseroan 1925. Produk hasil reformasi ini bersifat lebih sederhana (simplicitiy), netral (neutral), adil (equity), dan memberikan kepastian legal (legal certaity). ${ }^{1}$ Reformasi yang dilakukan ialah penerapan sistem self assesment menggantikan sistem official assesment. Sistem self assesment memberikan kepercayaan kepada wajb pajak untuk menghitung sendiri, melaporkan, dan melunasi kewajibannya. Sistem ini diterapkan melalui reformasi seperangkat undang-undang perpajakan seperti Undang-undang No 6 Tahun 1983 tentang Ketentuan Umum dan Tata Cara Perpajakan, Undang-undang No 7 Tahun 1983 tentang Pajak Penghasilan, dan Undangundang No 8 Tahun 1983 tentang PPN. Reformasi selanjutnya dalam bidang perpajakan dilakukan kembali dengan melakukan perubahan undang-undang pajak penghasilan tahun 1994 yang dilanjutkan dengan reformasi ketiga pada tahun 2000 dan keempat pada tahun 2007.

Pada dasarnya untuk mengerti reformasi yang terjadi pada administrasi perpajakan membutuhkan suatu pemahaman terhadap masalah itu sendiri. Banyak masalah yang timbul yang menjadikan suatu sistem perpajakan di suatu negara begitu rumit, sehingga membuat wajib pajak sebenarnya tidak mungkin untuk patuh. Kadang-kadang, sistem politik juga tidak mencari jalan keluar untuk mengurangi keluhan dari wajib pajak. Seringkali, masalah yang sebenarnya di dalam administrasi perpajakan adalah ada pada fiskus (pegawai pajak) sendiri. Masalah SDM yang kurang memiliki integritas, ketidakprofesioanalan (korupsi), dan tidak memiliki strategi yang brilian untuk memperbaiki administrasi perpajakan atas keluhan wajib pajak. Oleh karena itulah reformasi administrasi perpajakan harus dilakasanakan untuk memperbaiki efektivitas dan efisiensi dari administrasi perpajakan. Untuk itu, reformasi harus memperbaiki pelayanan, penegakan hukum (law enforcement), dan perbaikan pelaksanaan kode etik fiskus itu sendiri.

Berdasarkan latar belakang permasalahan diatas, maka dapat dirumuskan permasalahan, yaitu "bagaimana pengaruh penerapan sistem administrasi perpajakan modern terhadap kepatuhan wajib pajak orang pribadi di kota manado?”.

Tujuan dari penelitian ini adalah untuk mengetahui pengaruh penerapan sistem administrasi perpajakan modern terhadap kepatuhan wajib pajak orang pribadi di kota manado serta seberapa besar pengaruh tersebut.

\subsection{Hipotesis}

Berdasarkan perumusan masalah di atas, maka hipotesa yang digunakan adalah sebagai berikut.

Ho : Penerapan sistem administrasi perpajakan modern tidak memiliki pengaruh yang signifikan terhadap kepatuhan wajib pajak orang pribadi di kota manado.

Ha : Penerapan sistem administrasi perpajakan modern berpengaruh signifikan terhadap kepatuhan wajib pajak orang pribadi di kota manado.

\section{LANDASAN TEORI}

\subsection{Konsep Modernisasi Administrasi Perpajakan}

Sistem administrasi perpajakan modem ini adalah sebagai berikut.

1. Seluruh kegiatan administrasi dilaksanakan melalui sistem administrasi yang berbasis teknologi terkini.

2. Seluruh wajib pajak diwajibkan membayar melalui kantor penerima pembayaran secara online.

3. Seluruh wajib pajak diwajibkan melaporkan kewajiban perpajakannya dengan menggunakan media komputer (e-SPT). 
4. Monitoring kepatuhan wajib pajak dilaksanakan secara intensif dengan pemanfaatan profit Wajib Pajak.

5. Wajib pajak yang diadministrasikan di KPP Madya hanya wajib pajak tertentu saja, yaitu sekitar $500 \mathrm{WP}^{2}$

Setiap program yang dibuat dan dilaksanakan tentunya memiliki spesifikasi fungsi dan manfaat.Secara singkat, program modernisasi diharapkan dapat memberi manfaat bagi wajib pajak dan manfaat itu antara lain memberikan Pelayanan yang lebih baik, terpadu, dan personal, melalui:

1. konsep One Stop Service yang melayani seluruh jenis pajak (PPh, PPN, PBB \& BPHTB);

2. adanya tenaga Account Representative (AR) dengan tugas antara lain:

a. konsultasi untuk membantu segala permasalahan WP;

b. mengingatkan WP atas pemenuhan kewajiban perpajakannya;

c. update atas peraturan perpajakan yang terbaru;

3. Pemanfaatan IT secara maksimal: email, e-SPT, e-filing, dll;

4. SDM yang profesional yang meliputi:

a. adanya fit and proper test dan competency mapping;

b. pelaksanaan kode etik yang tegas dan konsisten;

c. pemberian tunjangan khusus (peningkatan remunerasi);

5. Pemeriksaan yang lebih terbuka dan profesional dengan konsep spesialisasi;

6. Pemeriksaan yang lebih terbuka dan profesional dengan konsep spesialisasi.

\subsection{Konsep Perpajakan}

Istilah pajak berasal dari bahasa Jawa, yaitu "ajeg", yang berarti pungutan teratur pada waktu tertentu. Pa-ajeg berarti pungutan teratur terhadap hasil bumi sebesar 40 persen dari yang dihasilkan petani untuk diserahkan kepada raja dan pengurus desa (Effendi, 2006:13).

Bermacam-macam batasan atau definisi tentang "pajak" yang dikemukakan oleh para ahli diantaranya adalah sebagai berikut.

1. Menurut P. J. A. Adriani, pajak adalah iuran masyarakat kepada negara (yang dapat dipaksakan) yang terutang oleh yang wajib membayarnya menurut peraturan-peraturan umum (undang-undang) dengan tidak mendapat prestasi kembali yang langsung dapat ditunjuk dan yang gunanya adalah untuk membiayai pengeluaran-pengeluaran umum berhubung tugas negara untuk menyelenggarakan pemerintahan.

2. Menurut H. Rochmat Soemitro, pajak adalah iuran rakyat kepada kas negara berdasarkan undang-undang (yang dapat dipaksakan) dengan tiada mendapat jasa timbal (kontra prestasi) yang langsung dapat ditunjukkan dan yang digunakan untuk membayar pengeluaran umum. Definisi tersebut kemudian dikoreksinya yang berbunyi sebagai berikut. Pajak adalah peralihan kekayaan dari pihak rakyat kepada kas negara untuk membiayai pengeluaran rutin dan surplusnya digunakan untuk public saving yang merupakan sumber utama untuk membiayai public investment.

Pajak mempunyai beberapa fungsi, yaitu sebagai berikut.

1. Fungsi anggaran (budgetair)

Sebagai sumber pendapatan negara, pajak berfungsi untuk membiayai pengeluaranpengeluaran negara. Dewasa ini pajak digunakan untuk pembiayaan rutin seperti belanja pegawai, belanja barang, pemeliharaan, dan lain sebagainya. Untuk pembiayaan pembangunan, uang dikeluarkan dari tabungan pemerintah, yakni penerimaan dalam negeri dikurangi pengeluaran rutin. Tabungan pemerintah ini dari tahun ke tahun harus ditingkatkan sesuai kebutuhan pembiayaan pembangunan yang semakin meningkat dan ini terutama diharapkan dari sektor pajak.

2. Fungsi mengatur (regulerend)

Dengan fungsi mengatur, pajak bisa digunakan sebagai alat untuk mencapai tujuan. Contohnya dalam rangka menggiring penanaman modal, baik dalam negeri maupun luar 
negeri, diberikan berbagai macam fasilitas keringanan pajak. Dalam rangka melindungi produksi dalam negeri, pemerintah menetapkan bea masuk yang tinggi untuk produk luar negeri.

3. Fungsi stabilitas

Dengan adanya pajak, pemerintah memiliki dana untuk menjalankan kebijakan yang berhubungan dengan stabilitas harga sehingga inflasi dapat dikendalikan. Hal ini bisa dilakukan antara lain dengan jalan mengatur peredaran uang di masyarakat, pemungutan pajak, penggunaan pajak yang efektif dan efisien.

4. Fungsi redistribusi pendapatan

Pajak yang sudah dipungut oleh negara akan digunakan untuk membiayai semua kepentingan umum, termasuk juga untuk membiayai pembangunan sehingga dapat membuka kesempatan kerja, yang pada akhirnya akan dapat meningkatkan pendapatan masyarakat.

Asas utama yang paling sering digunakan oleh negara sebagai landasan untuk mengenakan pajak adalah sebagai berikut.

1. Asas domisili atau disebut juga asas kependudukan (domicile/residence principle).

2. Asas sumber.

3. Asas kebangsaan atau asas nasionalitas atau disebut juga asas kewarganegaraan (nationality/citizenship principle).

Menurut R. Santoso Brotodiharjo, dalam bukunya Pengantar Ilmu Hukum Pajak, ada beberapa teori yang mendasari adanya pemungutan pajak, yaitu sebagai berikut.

1. Teori asuransi; menurut teori ini, negara mempunyai tugas untuk melindungi warganya dari segala kepentingannya baik keselamatan jiwanya maupun keselamatan harta bendanya. Untuk perlindungan tersebut diperlukan biaya seperti layaknya dalam perjanjian asuransi diperlukan adanya pembayaran premi. Pembayaran pajak ini dianggap sebagai pembayaran premi kepada negara. Teori ini banyak ditentang karena negara tidak boleh disamakan dengan perusahaan asuransi.

2. Teori kepentingan; menurut teori ini, dasar pemungutan pajak adalah adanya kepentingan dari masing-masing warga negara, termasuk kepentingan dalam perlindungan jiwa dan harta. Semakin tinggi tingkat kepentingan perlindungan, maka semakin tinggi pula pajak yang harus dibayarkan. Teori ini banyak ditentang, karena pada kenyataannya bahwa tingkat kepentingan perlindungan orang miskin lebih tinggi daripada orang kaya. Ada perlindungan jaminan sosial, kesehatan, dan lain-lain, bahkan orang yang miskin justru dibebaskan dari beban pajak.

Wajib pajak patuh adalah wajib pajak yang memenuhi kriteria sebagaimana yang ditetapkan oleh menteri keuangan yang dapat diberikan pembayaran pendahuluan, pengembalian kelebihan pajak. Kriteria wajib pajak patuh adalah sebagai berikut.

1. Tepat waktu dalam menyampaikan SPT untuk semua jenis pajak dalam 2 tahun terakhir.

2. Tidak mempunyai tunggakan untuk semua jenis pajak kecuali telah memperoleh izin untuk mengasur atau menunda pebayaran pajak.

3. Tidak pernah dijatuhi hukuman karena tindak pidana dalam perpajakn dalam waktu 10 tahun terakhir.

4. Dalam hal laporan keuangan diaudit oleh akuntan publik atau BPKP harus dengan wajar tanpa pengecualian atau dengan pendapat wajar dengan pengecualian sepanjang pengecualian tersebut tidak mempengaruhi fiskal.

Istilah Wajib Pajak (WP) dalam perpajakan indonesia merupakan istilah yang sangat populer. Istilah ini secara umum bisa diartikan sebagai orang atau badan yang dikenakan kewajiban pajak. Dalam undang-undang KUP lama, istilah wajib pajak didefinisikan sebagai orang pribadi atau badan yang menurut ketentuan peraturan perundang-undangan perpajakan ditentukan untuk melakukan kewajiban perpajakan, termasuk pemungut pajak atau pemotong pajak tertentu. Dari definisi ini kita 
dapat memahami bahwa wajib pajak ini terdiri dari dua jenis yaitu Wajib Pajak Orang Pribadi (WPOP) dan Wajib Pajak Badan. Namun demikian, kriteria siapa yang harus menjadi wajib pajak ini tidak dijelaskan. Berdasarkan ketentuan dalam pajak penghasilan, yang disebut wajib pajak itu adalah orang pribadi atau badan yang memenuhi definisi sebagai subjek pajak dan menerima atau memperoleh penghasilan yang merupakan objek pajak.

Dengan kata lain dua unsur harus dipenuhi untuk menjadi Wajib Pajak, yaitu Subjek Pajak dan Objek Pajak. $^{3}$

Dalam Undang-Undang No. 28 Tahun 2007 (UU KUP yang baru), definisi wajib pajak diubah menjadi :

"wajib pajak adalah orang pribadi atau badan, meliputi pembayar pajak, pemotong pajak, dan pemungut pajak, yang mempunyai hak dan kewajiban perpajakan sesuai dengan ketentuan peraturan perundang-undangan perpajakan".

Walaupun redaksinya berubah, namun sebenarnya tak ada perubahan substansi maknanya. Perubahan yang agak menonjol adalah ditambahkannya istilah pembayar pajak (tax payer) sebagai bagian wajib pajak.

Subjek pajak terdiri dari tiga jenis yaitu orang pribadi, warisan belum terbagi, badan dan Bentuk Usaha Tetap (BUT). Subjek pajak juga dibedakan menjadi subjek pajak dalam negeri dan subjek pajak luar negeri. Subjek pajak dalam negeri menjadi wajib pajak jika telah menerima atau memperoleh penghasilan sedangkan subjek pajak luar negeri sekaligus menjadi wajib pajak sehubungan dengan penghasilan yang diterima dari sumber penghasilan di Indonesia atau diperoleh melalui bentuk usaha tetap di Indonesia. Jadi, wajib pajak adalah orang pribadi atau badan yang telah memenuhi kewajiban subjektif dan objektif.

Yang dimaksud dengan subjek pajak dalam negeri adalah :

1. orang pribadi yang bertempat tinggal di indonesia;

2. orang pribadi yang berada di indonesia lebih dari 183 hari dalam jangka waktu 12 bulan;

3. orang pribadi yang dalam satu tahun pajak berada di indonesia dan mempunyai niat untuk bertempat tinggal di indonesia;

4. badan yang didirikan atau bertempat kedudukan di Indonesia;

5. warisan yang belum terbagi sebagai satu kesatuan, menggantikan yang berhak.

Apabila dikaitkan dengan kewajiban nomor pokok wajib pajak, maka yang wajib memiliki NPWP adalah :

1. semua subjek pajak badan dalam negeri;

2. subjek pajak orang pribadi dalam negei yang berpenghasilan di atas PTKP dalam satu tahun pajak;

3. Badan Usaha Tetap (BUT).

Ada beberapa pengelompokkan pajak yang kita ketahui dalam perpajakan, yaitu pajak menurut golongannya, menurut sifatnya dan menurut lembaga pemungutannya yang masing-masing diuraikan sebagai berikut.

1. Pajak menurut golongannya

Pajak menurut golongannya terbagi atas 2, yaitu:

a. pajak langsung, yaitu pajak yang harus dipikul sendiri oleh wajib pajak dan tidak dapat dibebankan atau dilimpahkan kepada orang lain. Contoh : Pajak Penghasilan (PPh);

b. pajak tidak langsung, yaitu pajak yang pada akhirnya dapat dibebankan atau dilimpahkan kepada orang lain. Contoh : Pajak Pertambahan Nilai (PPN).

2. Menurut sifatnya

Pajak menurut sifatnya terbagi atas 2, yaitu:

a. pajak subjektif, yaitu pajak yang berpangkal atau berdasarkan pada subjeknya, dalam arti memperhatikan keadaan diri wajib pajak.

Contoh : Pajak Penghasilan (PPh);

\footnotetext{
${ }^{3}$ (id.blogpajak by Dudy,2008)
} 
b. pajak objektif, yaitu pajak yang berpangkal pada objeknya, tanpa memperhatikan keadaan diri wajib pajak. Contoh : Pajak Pertambahan Nilai dan pajak penjualan atas barang mewah.

3. Menurut lembaga pemungutnya

Menurut lembaga pemungutannya, pajak terbagi atas 2 (dua) bagian, yaitu:

a. pajak pusat, yaitu pajak yang dipungut oleh pemerintah pusat dan digunakan untuk membiayai rumah tangga negara. Contoh : Pajak Penghasilan, Pajak Pertambahan Nilai dan Pajak Penjualan atas Barang Mewah, Pajak Bumi dan Bangunan, dan Bea Materai;

b. pajak daerah, yaitu pajak yang dipungut oleh pemerintah daerah dan digunakan untuk membiayai rumah tangga daerah. Pajak daerah terdiri atas pajak propinsi dan pajak kabupaten/kota. Pajak propinsi contohnya pajak kendaraan bermotor dan kendaraan di atas air, pajak bahan bakar kendaraan bermotor. Pajak kabupaten/kota contohnya pajak hotel, pajak restoran, pajak hiburan, pajak reklame, dan pajak penerangan jalan.

\section{METODOLOGI PENELITIAN}

Menurut Kuncoro (2003:124) data adalah keterangan mengenai sesuatu yang diperoleh dalam satu penelitian untuk menjelaskan, menerangkan, dan memecahkan masalah-masalah sesuai dengan konteks judul yang diambil dengan maksud dan tujuan. Jenis data dapat dibedakan menjadi dua jenis, yaitu sebagai berikut.

1. Data kualitatif

Data kualitatif merupakan data yang tidak dapat diukur dalam skala numerik atau data yang disajikan dalam bentuk deskriptif atau berbentuk uraian.

2. Data kuantitatif

Data kuantitatif merupakan data yang disajikan dalam bentuk skala numerik (angka).

Dalam melaksanakan analisis dan pembahasan terhadap masalah dalam penelitian ini menggunakan data kuantitatif berupa jawaban responden dalam kuesioner yang diukur dengan skala likert.

Menurut Indrianto (2002:146), sumber data dapat dibedakan menjadi dua bagian, yaitu sebagai berikut.

1. Data primer.

Data primer adalah data yang diperoleh langsung dari objek yang diteliti (tidak melalui perantara).

2. Data sekunder.

Data sekunder adalah data yang diperoleh peneliti secara tidak langsung melalui media perantara yaitu melalui hasil-hasil penelitian, buku-buku, artikel, dan berbagai publikasi serta instansi terkait yang relevan dengan masalah yang di angkat.

Sumber data yang digunakan dalam penelitian ini adalah data primer, yaitu data yang diperoleh melalui kuesioner yang dibagikan kepada wajib pajak orang pribadi yang berdomisili di daerah malalayang dan terdaftar di KKP pratama manado dan dianggap memenuhi syarat.

Secara umum ada banyak teknik pengumpulan data yang dikenal dan dapat digunakan dalam pengumpulan data. Teknik pengumpulan data yang digunakan dalam penelitian ini adalah survei lapangan, dimana peneliti membagikan angket atau kuesioner yang berupa daftar pertanyaan kepada responden untuk diisi serta wawancara langsung dengan responden dalam hal ini wajib pajak orang pribadi dan staff yang bekerja di KPP pratama manado. Tujuannya adalah untuk memperoleh data yang relevan dari responden.

Populasi adalah kelompok elemen yang lengkap, yang biasanya berupa orang, objek, transaksi, atau kejadian dimana kita tertarik untuk mempelajarinya atau menjadi objek penelitian (Kuncoro, 2003: 103). Populasi dari penelitian ini adalah sejumlah wajib pajak orang pribadi yang berdomisili di daerah kecamatan malalayang dan terdaftar di KPP pratama manado sampai tahun 2010.

Sampel adalah sebagian dari jumlah dan karakterisitik yang dimiliki oleh populasi (Sugiyono, 1997:57). Dengan menggunakan metode purposive sampling, yaitu teknik pengambilan sampel yang dugunakan oleh peneliti jika peneliti mempunyai pertimbangan-pertimbangan tertentu dalam 
pengambilan sampelnya atau penentuan sampel untuk tujuan tertentu (Ridwan, 2004:63), maka untuk pemilihan sampel dalam penelitian ini dilakukan dengan melihat wajib pajak orang pribadi yang berdomisili di daerah kecamatan malalayang dan dianggap memiliki karakteristik yang sesuai dengan topik. Berdasarkan kriteria tersebut, maka ditentukan jumlah wajib pajak orang pribadi yang akan dijadikan sampel sebanyak 100 orang, yang diperoleh dengan menggunakan rumus slovin (Umar, 2005 : 108) sebagai berikut.

Tabel 3.1 Jumlah WPOP di Kecamatan Malalayang

Sumber data: data olahan dari KPP pratama manado

\begin{tabular}{|c|c|}
\hline Data per kelurahan & Jumlah \\
\hline Bahu & 2.762 \\
Batu Kota & 821 \\
Kleak & 2.090 \\
Malalayang I & 4172 \\
Malalayang II & 1.633 \\
Winangun I & 1.876 \\
Winangun II & 667 \\
\hline Total & $\mathbf{1 4 . 0 2 1}$ \\
\hline
\end{tabular}

Rumus Slovin :

$$
n=\frac{N}{1+N e^{2}}
$$

\section{Keterangan :}

$\mathrm{n}$ : Ukuran sample

$\mathrm{N}$ : Ukuran populasi

e : Persentase kelonggaran ketidaktelitian karena kesalahan pengambilan sampel yang masih dapat ditolerir atau diinginkan, sebesar $10 \%$.

$$
\begin{aligned}
\mathrm{N} & =14.021 \\
\mathrm{e} & =10 \%(0,1) \\
\mathrm{n} & =\frac{14.021}{1+14.021(0,1)^{2}} \\
\mathrm{n} & =\frac{14.021}{1+14.021(0,01)} \\
\mathrm{n} & =\frac{14.021}{141.21} \\
\mathrm{n} & =99,291 \\
\mathrm{n} & =99,291 \text { dibulatkan menjadi } 100
\end{aligned}
$$

Pengujian validitas dilakukan dengan cara mengkorelasikan antara skor masing-masing butir pertanyaan dengan skor total yang diperoleh dari penjumlahan semua skor pertanyaan. Bila korelasi tersebut signifikan, maka alat ukur yang digunakan mempunyai validitas. Selanjutnya, dengan menggunakan angka kritis dari $\mathrm{r}$ tabel (tabel $\mathrm{r}$ product moment) dengan taraf signifikan 5\%. Jika koefisien korelasi $(\mathrm{R})>0.3$ maka pertanyaan tersebut dinyatakan valid, sebaliknya jika koefisian korelasi (R) yang diperoleh lebih kecil dari $r$ tabel maka pertanyaan tersebut tidak valid (Sumarsono,2004:31).

Pengujian reliabilitas dilakukan untuk mengetahui apakah jawaban yang diberikan responden dapat dipercaya atau dapat diandalkan dengan menggunakan analisis reliability melalui metode cronbach alpha, dimana suatu instrumen dikatakan reliabel bila memiliki koefisien keandalan atau alpha sebesar 0,6 atau lebih (Sumarsono, 2004:34). 
Tabel 3.2

Tingkat Reliabilitas Berdasarkan Cronbach Alpha

Sumber : sumarsono, 2004

\begin{tabular}{|c|c|}
\hline Alpha & Tingkat Reliabilitas \\
\hline $0,00 \mathrm{~s} / \mathrm{d} 0,20$ & Kurang reliabel \\
$>0,20 \mathrm{~s} / \mathrm{d} 0,40$ & Agak reliabel \\
$>0,40 \mathrm{~s} / \mathrm{d} 0,60$ & Cukup reliabel \\
$>0,60 \mathrm{~s} / \mathrm{d} 0,80$ & Reliabel \\
$>0,80 \mathrm{~s} / \mathrm{d} 1,00$ & Sangat reliabel \\
\hline
\end{tabular}

Setelah data yang diperoleh cukup memadai dari segi validitas dan reliabilitasnya, maka langkah selanjutnya adalah menganalisis data. Metode analisa yang digunakan dalam penelitian ini adalah sebagai berikut.

1. Statistik Deskriptif

Dalam menganalisa data penelitian yang akan menggunakan analisis statistik deskriptif merupakan proses transformasi data penelitian dalam bentuk tabulasi sehingga mudah dipahami dan diinterpretasikan. Tabulasi menyajikan ringkasan, pengaturan, atau penyusunan data dalam bentuk tabel numerik atau grafik. Statistik deskriptif umumnya digunakan oleh peneliti untuk memberikan informasi karakteristik variabel penelitian yang utama dan data demografi responden (jika ada) (Kuncoro, 2003:172).

2. Uji Asumsi Klasik

Agar hasil regresi yang digunakan untuk memprediksi variabel terkait tidak membias dan untuk lebih meyakinkan adanya kesesuaian antara model persamaan regresi maka digunakan asumsi klasik menurut ekonometrika yang harus dipenuhi oleh suatu model regresi. Asumsi klasik tersebut adalah uji normalitas dan bebas heteroskedastisitas.

a. Uji normalitas, digunakan untuk mengetahui apakah data penelitian berdistribusi normal atau tidak. Uji normalitas data dapat dilakukan dengan berbagai cara antara lain uji chi kuadrat $\left(\mathrm{x}^{2}\right)$. Dengan kriteria sebagai berikut.Jika probabilitas (asymp.sig) $>\alpha 0,05$ maka distribusi data tidak normal dan Jika probabilitas (asymp.sig) $<\alpha 0,05$ maka distribusi data normal.

b. Asumsi klasik heteroskedastisitas. Heteroskedastisitas dapat diartikan sebagai ketidaksamaan variasi variabel pada semua pengamatan dan kesalahan yang terjadi memperlihatkan hubungan yang besarnya satu atau lebih variabel bebas sehingga kesalahan tersebut tidak random (acak). Untuk mendeteksi ada tidaknya heteroskedastisitas dapat dilakukan dengan melihat ada tidaknya pola tertentu pada grafik plot (scatter plot). Jika tidak membentuk suatu pola berarti bebas heteroskedastisitas.

Metode analisis yang digunakan dalam penelitian ini adalah menggunakan analisis regresi linear sederhana, yaitu suatu formula yang mencari nilai variabel dependen dari nilai variabel independen yang di ketahui dengan menggunakan rumus :

Dimana :

$$
\mathrm{Y}=\mathrm{a}+\mathrm{bX}+\mathrm{e}
$$

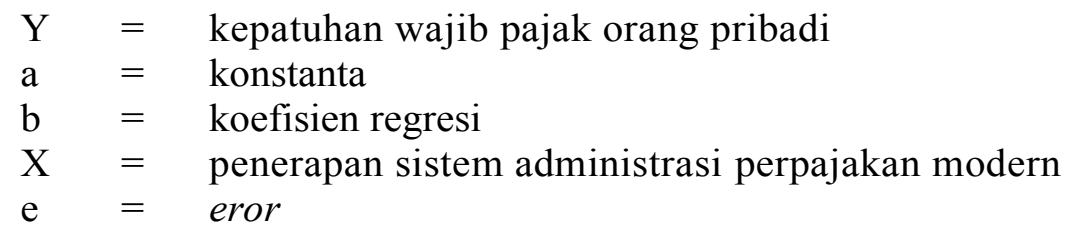

Hipotesis yang diajukan menggunakan statistik uji t. Uji t adalah pengujian yang dilakukan untuk mengetahui dan menunjukan berapa pengaruh suatu variabel penjelas secara individu dalam menerangkan variabel-variabel terikat.

Hipotesa dirumuskan sebagai berikut.

$\mathrm{H}_{0}: \beta_{1}=0 \quad$ artinya variabel penerapan sistem administrasi perpajakan modern tidak berpengaruh signifikan terhadap kepatuhan wajib pajak orang pribadi. 
$\mathrm{H}_{\mathrm{a}}: \beta_{1} \neq 0$ artinya variabel penerapan sistem administrasi perpajakan modern berpengaruh signifikan terhadap kepatuhan wajib pajak orang pribadi.

Dengan kriteria pengujian jika $t_{\text {hitung }}>t_{\text {tabel }}$ maka $\mathrm{H}_{0}$ ditolak atau signifikan $<0,05$ dan jika $\mathrm{t}_{\text {hitung }}<$ $t_{\text {tabel }}$ maka $\mathrm{H}_{0}$ diterima atau signifikan $>0,05$. $t_{\text {tabel }}$ dapat dicari pada taraf kepercayaan $95 \%(\alpha=5 \%)$ dan derajat bebas (df) $n-1$ atau 16-1 = 15 .

Analisis koefisien korelasi (R) ini digunakan untuk mengukur keeratan hubungan antara variabel bebas $(\mathrm{X})$ terhadap variabel terikat $(\mathrm{Y})$, dalam hal ini mengukur kuat lemahnya hubungan antara penerapan sistem administrasi perpajakan modern $(\mathrm{X})$ dengan kepatuhan wajib pajak orang pribadi (Y). Kemudian, koefisien determinasi $\left(\mathrm{R}^{2}\right)$ diperlukan untuk mengukur seberapa besar kontribusi yang diberikan oleh penerapan sistem administrasi perpajakan modern (X) terhadap kepatuhan wajib pajak orang pribadi (Y).

\section{HASIL PENELITIAN DAN PEMBAHASAN}

\subsection{Analisis Hasil Penelitian}

Seluruh responden yang mengisi kuesioner atau yang memberikan data adalah pemilik usaha dengan tingkat pendidikan yang di sajikan di dalam Tabel 4.1 .

Tabel 4.1

Komposisi Responden Berdasarkan Jabatan dan Pendidikan

\begin{tabular}{|l|l|c|c|}
\hline No & Tingkat pendidikan & Jumlah & Persentase \\
\hline 1 & Sarjana & 38 orang & $38 \%$ \\
2 & Diploma & 17 orang & $17 \%$ \\
3 & SMA & 45 orang & $45 \%$ \\
\hline \multicolumn{2}{|c|}{ Total } & 100 orang & $\mathbf{1 0 0} \%$ \\
\hline
\end{tabular}

Sumber : data olahan 2011

Dari kuesioner yang telah dikembalikan oleh responden yaitu sebanyak 100 orang atau 100 wajib pajak orang pribadi, dimana yang mengisi kuesioner yaitu pemilik usaha itu sendiri dirangkum dalam bentuk tabulasi sesuai dengan klasifikasinya. Untuk variabel penerapan sistem administrasi perpajakan modern terdapat 5 pertanyaan dan untuk variabel kepatuhan wajib pajak orang pribadi juga terdapat 5 pertanyaan.jadi dari dua variabel yang di ukur, keseluruhan pertanyaan berjumlah 10 pertanyaan.

Data utama yang digunakan dalam penelitian ini adalah data primer, dengan kuesioner sebagai alat utama untuk memperoleh data. Oleh karena itu, untuk meyakinkan akan kualitas data yang akan diolah, terlebih dahulu diuji validitas dan reliabilitasnya sebagai berikut.

1. Uji validitas

Pada penelitian ini data yang digunakan dinyatakan valid. Hal ini di buktikan melalui pengujian SPSS Version 17 dan ditunjukkan pada tabel 4.2.

\section{Tabel 4.2.}

Hasil Uji Validitas

\begin{tabular}{|l|l|l|l|l|}
\hline \multicolumn{5}{|c|}{ X } \\
\hline No & Pertanyaan & \multicolumn{1}{|c|}{ R } & Sig & Keterangan \\
\hline 1 & P1 & 0,741 & 0.000 & Valid \\
\hline 2 & P2 & 0,426 & 0.000 & Valid \\
\hline 3 & P3 & 0,693 & 0.000 & Valid \\
\hline 4 & P4 & 0,513 & 0.000 & Valid \\
\hline 5 & P5 & 0,556 & 0.000 & Valid \\
\hline \multicolumn{5}{|l}{} \\
\hline 1 & P1 Y & 0.000 & Valid \\
\hline 2 & P2 & $0,604 \quad 0,622$ & 0.000 & Valid \\
\hline 3 & P3 & 0,728 & 0.000 & Valid \\
\hline 4 & P4 & 0,641 & 0.000 & Valid \\
\hline
\end{tabular}




\begin{tabular}{|c|l|l|l|l|}
\hline 5 & P5 & 0,687 & 0.000 & Valid \\
\hline
\end{tabular}

Dilihat dari hasil pengujian validitas antara kepatuhan wajib pajak orang pribadi dan sistem administrasi perpajakan modern dinyatakan valid karena nilai lebih besar dari corelation product momment sebesar 0,3 .

2. Uji reliabilitas

Setelah data dinyatakan valid selanjutnya dilakukan uji reliabilitas. Dapat dilihat pada Tabel 4.3.

Tabel 4.3. Hasil Uji Reliabilitas

\begin{tabular}{|c|c|c|c|}
\hline No & Pertanyaan & Nilai alpha & Keterangan \\
\hline 1 & $\mathrm{X}$ & 0,730 & Reliabel \\
\hline 2 & $\mathrm{Y}$ & 0,758 & Reliabel \\
\hline
\end{tabular}

Sumber : data hasil olahan SPSS 17

Dilihat dari hasil pengujian reliabilitas variabel bebas dan variabel terikat dinyatakan reliabel karena lebih besar dari nilai reliabilty sebesar 0,6 dengan menggunakan analisis reliability melalui metode cronbach alpha yang diukur berdasarkan skala alpha 0 sampai dengan 1. Setelah data diolah dengan menggunakan software program SPSS version 17.

berikut.

Adapun hasil uji dari metode analisis data yang digunakan dalam penelitian ini adalah sebagai

1. Statistik deskriptif

Berdasarkan hasil perhitungan menggunakan software program SPSS version 17 maka rata-rata hitung dan standar deviasi dari masing-masing variabel seperti yang ditunjukan dalam Tabel 4.4.

Tabel 4.4. Descriptive Statistics

\begin{tabular}{|l|r|r|r|}
\hline & Mean & Std. Deviation & \multicolumn{1}{|c|}{ N } \\
\hline $\mathrm{Y}$ & 20.99 & 2.181 & 100 \\
$\mathrm{X}$ & 20.63 & 1.926 & 100 \\
\hline
\end{tabular}

Sumber data : data primer yang diolah, 2011

Dari tabel di atas dapat dilihat bahwa untuk variabel bebas sistem administrasi perpajakan modern (X) memperoleh rata-rata hitung sebesar 20.63 dan standar deviasi 1.926. Kemudian variabel kepatuhan wajib pajak orang pribadi (Y) memperoleh rata-rata hitung sebesar 20.99 dan standar deviasi 2.181 yang menunjukkan bahwa responden memiliki pemahaman bahwa sistem adminidtrsasi perpajakan modern memiliki peranan dalam peningkatan kepatuhan WPOP di kota manado dan sebaliknya.

2. Asumsi klasik

Berdasarkan hasil perhitungan menggunakan software program SPSS 17 maka diperoleh hasil sebagai berikut.

a. Uji normalitas

Uji normalitas digunakan untuk mengetahui apakah data dalam penelitian berdistribusi normal atau tidak. Uji normalitas data dilakukan dengan berbagai cara antara lain dapat dilihat pada gambar normal p-p plot normal regresion standardized residual dimana sebaran data mengikuti arah garis diagonal. Artinya semua variabel bebas terdistribusi secara normal dan untuk pemnelitian ini dapat dilihat pada Gambar 4.5. 


\section{Gambar 4.2}

\section{Uji Asumsi Klasik Normalitas}

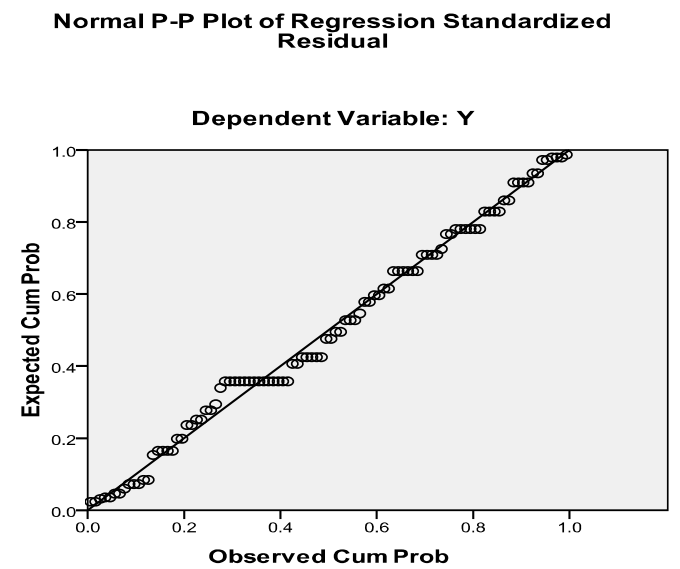

b. Uji heteroskedastisitas

Heteroskedastisitas dapat diartikan sebagai ketidaksamaan variasi variabel pada semua pengamatan dan kesalahan yang terjadi memperlihatkan hubungan yang besarnya satu atau lebih variabel bebas sehingga kesalahan tersebut tidak random (acak). Untuk mendeteksi ada tidaknya heteroskedastisitas, dapat dilakukan dengan melihat ada tidaknya pola tertentu pada grafik plot (scatter plot). Jika tidak membentuk suatu pola, berarti bebas heteroskedastisitas.

\section{Gambar 4.3}

\section{Hasil Uji Heteroskedastisitas}

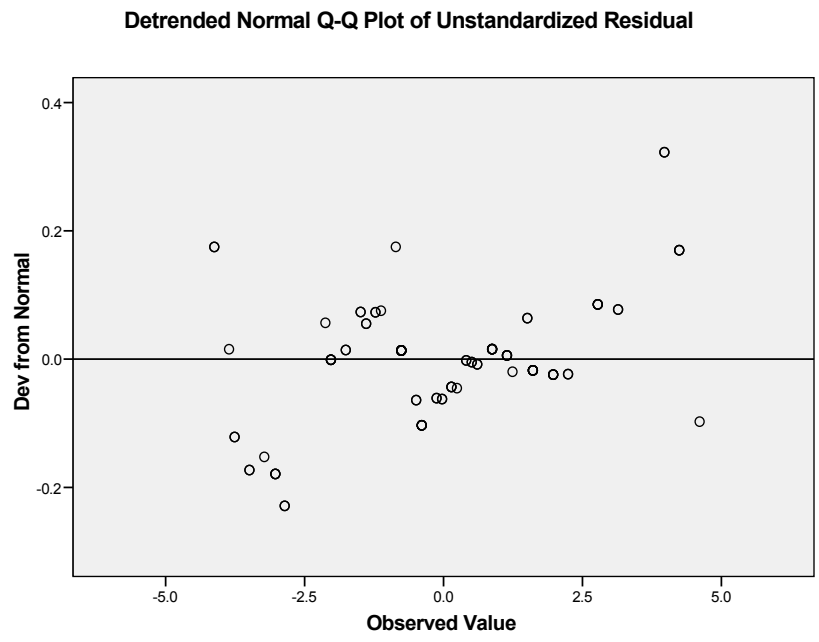

Gambar 4.6 grafik Scatterplot yang ditampilkan untuk uji heterokesdastisitas menampakkan titik-titik disekitar 0 yang menyebar secara acak. Hal tersebut mengidentifikasikan bahwa tidak terjadinya heterokesdastisitas pada model regresi, sehingga model regresi tersebut layak dipakai untuk memprediksi variabel dependen 
kepatuhan wajib pajak orang pribadi berdasarkan masukkan variabel independen penerapan sistem administrasi perpajakan modern.

Berdasarkan hasil perhitungan data dengan menggunakan bantuan program SPSS version 17, maka hasil perhitungan regresi linier sederhana dapat dilihat dalam Tabel 4.7.

\section{Tabel 4.7 Hasil Analisis Regresi Linear Sederhana}

Coefficients $^{\mathrm{a}}$

\begin{tabular}{|l|r|r|r|r|r|}
\hline \multirow{2}{*}{ Model } & \multicolumn{2}{|c|}{$\begin{array}{c}\text { Unstandardized } \\
\text { Coefficients }\end{array}$} & $\begin{array}{c}\text { Standardized } \\
\text { Coefficients }\end{array}$ & & \multirow{2}{*}{ Sig. } \\
\cline { 2 - 4 } & \multicolumn{1}{|c|}{$\mathrm{B}$} & Std. Error & \multicolumn{1}{|c|}{ Beta } & \multicolumn{1}{c|}{$\mathrm{T}$} & \multicolumn{1}{c|}{ Sig. } \\
\hline 1 (Constant) & 13.428 & 2.242 & & 5.989 & .000 \\
$\mathrm{X}$ & .367 & .108 & .324 & 3.387 & .001 \\
\hline
\end{tabular}

a. Dependent Variable: (Y) kepatuan wajib pajak orang pribadi kota manado

Sumber: data olahan SPSS 17

Dari tabel 4.7 maka dapat diketahui model regresi yang diperoleh adalah

$$
\begin{gathered}
\mathbf{Y}=\mathbf{a}+\mathbf{b X}+\mathbf{e} \\
\mathrm{Y}=13,428+0,367 \mathbf{X}+\mathrm{e}
\end{gathered}
$$

Persamaan diatas memperlihatkan nilai dari koefisien $X$ sebesar positif $(0,367)$. Ini berarti variabel penerapan sistem administrasi perpajakan modern berpengaruh positif terhadap kepatuhan wajib pajak. Apabila penerapan sistem administrasi perpajakan modern mengalami peningkatan maka kepatuhan wajib pajak orang pribadi juga akan meningkat. Sebaliknya, apabila penerapan sistem administrasi perpajakan modern mengalami penurunan maka kepatuhan wajib pajak orang pribadi juga akan menurun.

Perumusan hipotesis yang diuji, telah dikemukakan dalam Bab III di depan dengan tingkat signifikansi yang digunakan dalam penelitian ini sebesar 5\% atau $\alpha=0,05$ maka, hasil pengujian hipotesis tersebut dapat dilihat melalui uji parsial (Uji t). Dengan menggunakan bantuan software program SPSS version 17 maka hasil $t_{\text {hitung }}$ dapat dilihat dalam Tabel 4.7.

Dari hasil uji $t$ diketahui $t_{\text {hitung }}$ untuk variabel pengetahuan wajib pajak $=3,387$ dan $t_{\text {tabel }}=1,660$. Jadi dapat dilihat bahwa $t_{\text {hitung }}>t_{\text {tabel }}$ maka $\mathrm{H}_{0}$ ditolak $\mathrm{H}_{\mathrm{a}}$ diterima, juga dapat dilihat dari hasil signifikan $<0,05$ maka $\mathrm{H}_{0}$ ditolak $\mathrm{H}_{\mathrm{a}}$ diterima, artinya variabel sistem admininstrasi perpajakan modern berpengaruh positif dan signifikan terhadap kepatuhan wajib pajak orang pribadi.

Analisis koefisien korelasi (R) ini digunakan untuk mengukur keeratan hubungan antara variabel bebas $(\mathrm{X})$ terhadap variabel terikat $(\mathrm{Y})$, dalam hal ini mengukur kuat lemahnya hubungan antara penerapan sistem administrasi perpajakan modern $(\mathrm{X})$ dengan kepatuhan wajib pajak orang pribadi (Y). Kemudian, koefisien determinasi $\left(\mathrm{R}^{2}\right)$ diperlukan untuk mengukur seberapa besar kontribusi yang diberikan oleh sistem administrasi perpajakan modern $(\mathrm{X})$ terhadap kepatuhan wajib pajak orang pribadi (Y).

Dengan menggunakan bantuan software program SPSS version 17 maka, hasil koefisien korelasi (R) dan koefisien determinasi $\left(\mathrm{R}^{2}\right)$ dapat dilihat dalam Tabel 4.8.

\section{Tabel 4.8}

Hasil Pengujian Koefisien Korelasi dan Koefisien Determinasi

\begin{tabular}{|c|c|c|c|c|c|c|c|c|c|c|}
\hline \multirow[b]{2}{*}{ Model } & \multirow[b]{2}{*}{$\mathrm{R}$} & \multirow[b]{2}{*}{$\begin{array}{c}\mathrm{R} \\
\text { Square }\end{array}$} & \multirow[b]{2}{*}{$\begin{array}{c}\text { Adjuste } \\
\text { d R } \\
\text { Square }\end{array}$} & \multirow[b]{2}{*}{$\begin{array}{c}\text { Std. } \\
\text { Error of } \\
\text { the } \\
\text { Estimat } \\
\text { e }\end{array}$} & \multicolumn{5}{|c|}{ Change Statistics } & \multirow[b]{2}{*}{$\begin{array}{c}\text { Durbi } \\
\text { n- } \\
\text { Wats } \\
\text { on }\end{array}$} \\
\hline & & & & & $\begin{array}{c}\text { R } \\
\text { Square } \\
\text { Change }\end{array}$ & $\begin{array}{c}\text { F } \\
\text { Chang } \\
\text { e }\end{array}$ & df1 & $\mathrm{df} 2$ & $\begin{array}{l}\text { Sig. } \\
\text { F } \\
\text { Chan } \\
\text { ge }\end{array}$ & \\
\hline 1 & $.324^{\mathrm{a}}$ & .105 & .096 & 2.074 & .105 & $\begin{array}{r}11.46 \\
9\end{array}$ & 1 & 98 & .001 & 2.378 \\
\hline
\end{tabular}
Model Summary ${ }^{\text {b }}$ 


\begin{abstract}
a. Predictors: (Constant): $\mathrm{X}$
b. Dependent Variable: $Y$

Sumber : data hasil olahan SPSS 17
\end{abstract}

Koefisien korelasi yang digunakan untuk mengukur besarnya pengaruh variabel bebas yakni X, yang digunakan dalam persamaan regresi ini mempengaruhi variabel terikat yakni Y yang ditunjukkan oleh angka 0.105. Angka ini memberikan arti kurangnya hubungan antara variabel bebas tersebut terhadap variabel terikat.

Untuk melihat besarnya kontribusi seluruh variabel bebas terhadap variabel terikat $(\mathrm{Y})$, ditunjukkan oleh angka koefisien determinasi sebesar 0,324. Angka ini menunjukkan besarnya sumbangan variabel bebas terhadap variabel terikat (Y) sebesar 32,4\%; sedangkan sisanya disebabkan oleh faktor lain yang tidak diteliti dalam penelitian ini.

\title{
4.2 Pembahasan
}

Dalam pedoman untuk memberikan interprestasi hubungan terhadap koefisien korelasi, dimana apabila koefisien berada diantara 0,30 - 0,50 maka nilai tersebut berada pada tingkat hubungan yang lemah antara kedua variabel. Pada tabel 4.8 hasil analisis koefisien korelasi menghasilkan nilai koefisien korelasi 0,324. Hal ini berarti, telah terjadi hubungan yang lemah antara variabel $\mathrm{X}$ (penerapan sistem administrasi perpajakan modern) dan variabel Y (kepatuhan wajib pajak orang pribadi). Hubungan antara kedua variabel juga bersifat positif atau searah. Dapat di lihat pada tabel 4.7 yang merupakan hasil pengujian analisis regresi linear sederhana $(\mathrm{Y}=13,428+0,367 \mathrm{X}+\mathrm{e})$ yang berarti apabila penerapan sistem administrasi perpajakan modern meningkat, maka kepatuhan wajib pajak orang pribadi di kota manado juga akan mengalami peningkatan. Sebaliknya, apabila jumlah penerapan sistem admministrasi perpajakan modern menurun, maka kepatuhan wajib pajak orang pribadi di kota manado juga akan mengalami penurunan.

Hasil analisis koefisien determinasi yang menghasilkan nilai koefisien detrminasi 0,105 dimana dapat memberikan pengertian bahwa10,5 \% kepatuhan wajib pajak orang pribadi di kota manado mampu dijelaskan oleh penerapan sistem administrasi perpajakan modern. Sedangkan sisanya $89,5 \%$ dijelaskan oleh faktor - faktor lain yang tidak diteliti dalam penelitian ini. Hal ini berarti bahwa sistem administrasi perpajakan modern mempunyai pengaruh yang signifikan terhadap kepatuhan wajib pajak orang pribadi di kota manado.

Hasil pengujian hipotesis dilakukan untuk menentukan apakah hipotesis yang diajukan ditolak atau diterima, yaitu sebagai berikut.

$\mathrm{H}_{0} \quad$ : tidak terdapat pengaruh signifikan penerapan sistem administrasi perpajakan modern terhadap kepatuhan wajib pajak orang pribadi di kota Manado.

$\mathrm{H}_{\mathrm{a}} \quad$ : terdapat pengaruh signifikan penerapan sistem administrasi perpajakan modern terhadap kepatuhan wajib pajak orang pribadi di kota Manado.

Dari hasil uji t pada tabel 4.7 diketahui $t_{\text {hitung }}$ untuk variabel pengetahuan wajib pajak $=3,387$ dan $t_{\text {tabel }}=1$,660. Jadi dapat dilihat bahwa $t_{\text {hitung }}>t_{\text {tabel }}$ maka $\mathrm{H}_{0}$ ditolak $\mathrm{H}_{\mathrm{a}}$ diterima, juga dapat dilihat dari hasil signifikan $<0,05$ maka $\mathrm{H}_{0}$ ditolak $\mathrm{H}_{\mathrm{a}}$ diterima, artinya variabel sistem admininstrasi perpajakan modern berpengaruh signifikan terhadap kepatuhan wajib pajak orang pribadi.

\section{PENUTUP}

\subsection{Kesimpulan} berikut.

Berdasarkan hasil pembahasan pada bab sebelumnya, maka dapat ditarik kesimpulan sebagai

1. Berdasarkan hasil penelitian yang diperoleh dari analisis regresi linear sederhana bahwa penerapan sistem administrasi perpajakan modern berpengaruh terhdap kepatuhan wajib pajak orang pribadi di kota Manado. Didapatkan persamaan regresi linier sederhana $\mathrm{Y}=13,428$ $+0.367 \mathrm{X}+$ e yang memperlihatkan nilai dari koefisien $\mathrm{X}$ sebesar positif $(0,367)$. Ini berarti variabel penerapan sistem administrasi perpajakan modern berpengaruh positif terhadap kepatuhan wajib pajak. Apabila penerapan sistem administrasi perpajakan modern mengalami peningkatan maka kepatuhan wajib pajak orang pribadi juga akan meningkat. Sebaliknya, 
apabila penerapan sistem administrasi perpajakan modern mengalami penurunan maka kepatuhan wajib pajak orang pribadi juga akan menurun.

2. Berdasarkan penelitian yang diperoleh dari hasil analisis koefisien korelasi menghasilkan nilai koefisien korelasi 0,324. Hal ini berarti terjadi hubungan yang lemah antara variabel $\mathrm{X}$ (penerapan sistem administrasi perpajakan modern) dan variabel Y (kepatuhan wajib pajak orang pribadi). Hubungan antara kedua variabel juga bersifat positif atau searah, yang berarti apabila penerapan sistem administrasi perpajakan modern dilaksanakan dengan baik, maka kepatuhan wajib pajak orang pribadi di kota manado juga akan mengalami peningkatan namun sebaliknya apabila penerapan sistem administrasi perpajakan modern mengalami penurunan, maka tingkat kepatuhan wajib pajak orang pribadi di kota manado juga akan mengalami penurunan.

3. Berdasarkan hasil pengujian hipotesis uji t, maka dapat diketahui bahwa variabel jumlah objek pajak $(X) t_{\text {hitung }}=3,387>t_{\text {tabel }}=1,660$. Dengan demikian hasil uji $t$ menyatakan bahwa $\mathrm{H}_{\mathrm{a}}$ diterima dan $\mathrm{H}_{0}$ ditolak karena $\quad t_{\text {hitung }}>t_{\text {tabel }}$. Artinya variabel penerapan sistem administrasi perpajakan modern ( $\mathrm{X}$ ) berpengaruh secara signifikan terhadap kepatuhan wajib pajak orang pribadi di kota Manado (Y) yang juga berarti bahwa dengan adanya penerapan sistem administrasi perpajakan modern yang baik maka akan meningkatkan kepatuhan wajib pajak orang pribadi di kota Manado.

\subsection{Saran}

Berdasarkan kesimpulan yang ada, maka dapat diberikan beberapa saran sebagai berikut.

1. Bagi instansi terkait dalam hal ini kantor pelayanan pajak untuk tetap melanjutkan penerapan sistem administrasi perpajakan modern tersebut secara optimal serta memperbanyak sosialisasi kepada masyarakat yang kurang mengerti tentang hal-hal baru yang berhubungan dengan sistem administrasi tersebut yang selama ini tidak dimengerti sehingga tidak ada lagi alasan bagi wajib pajak untuk tidak membayar pajak pada waktu yang telah ditentukan.

2. Bagi wajib pajak orang pribadi agar dapat memanfaatkan setiap kemudahan dari sistem administrasi perpajakan modern yang sudah disediakan serta berusaha agar mengerti akan halhal yang berhubungan dengan sistem tersebut.

\section{DAFTAR PUSTAKA}

Anggota IKAPI, 2010, Undang - Undang Ketentuan Umun dan Tata Cara

Perpajakan (KUP) susunan

dalam satu naskah, edisi revisi, Fokusmedia. Bandung.

Brotodihardjo, 2010, Pengantar Ilmu Hukum Pajak, edisi revisi, penerbit Eresco, Jakarta

Effendi, 2006, Kebijakan Perpajakan di Indonesia dari Era Kolonial Sampai Era Orde Baru, Alinea Pustaka, Jogjakarta.

Khaerani , 2010, Pengaruh Penerapan Sistem Administrasi Perpajakan Modern terhadap Kepatuhan Wajib

Pajak Orang Pribadi

Mardiasmo, 2009, Perpajakan, edisis revisi, ANDI, Yogyakarta.

Niko, 2010, Pengaruh Penerapan Sistem Administrasi Perpajakan Modern

Terhadap Kepatuhan Wajib

Pajak pada KPP Wajib Pajak Besar I dan II.

Riduwan, 2009, Belajar mudah penelitian, penerbit Alfabeta, Jakarta. 
Suprianto, 2010, Perpajakan Indonesia, Graha ilmu, Yogyakarta.

Tjahjono, ahmad dan husain, muhammad, 1997, perpajakan, edisi 1, penerbit UPP AMP YKPN.

Waluyo, ilyas dan irawan, 2000, Perpajakan Indonesia, Penerbit salemba empat Jakarta.

Waluyo, 2010, Perpajakan indonesia, penerbit salemba empat jakarta.

Wijayanti, 2010, Pengaruh Reformasi Administrasi Perpajakan Dari Segi Modernisasi Prosedur Organisasi Terhadap Kepatuhan Wajib Pajak Dalam Memenuhi Kewajiban Perpajakan (studi kasus pada wajib pajak di wilayah surakarta)

2010, Sejarah dan Perkembangan KPP Pratama Manado, Manado. 